\title{
Bacterial Adherence to Different Inert Surfaces Evaluated by Epifluorescence Microscopy and Plate Count Method
}

\author{
Silvânia Quintão Fontes Parizzi, Nélio José de Andrade*, Cleuber Antonio de Sá Silva, \\ Nilda de Fátima Ferreira Soares and Eldo Antônio Monteiro da Silva \\ Departamento de Tecnologia de Alimentos; UFV; nandrade@ufv.br; Viçosa-Brazil
}

\begin{abstract}
The adherence of Listeria inoccua L6a and Staphylococcus aureus ATCC6538 was evaluated on stainless steel (SS), polycarbonate $(P C)$ and polypropylene $(P P)$ chips. The EP results showed a significant difference $(p<0.05)$ among the microorganism species interactions, the surfaces and the contact time. The number of adhered cells on the chip surfaces increased as contact time increased and the number of $\underline{L}$. innocua or $\underline{S}$. aureus on the surface of SS, PC and PP chips reached $1.0 \times 10^{5} \mathrm{CFU} / \mathrm{cm}^{2}$ after $12 \mathrm{~h}$ of contact, in both methods. The CP method showed a better sensitivity to detect low number of adhered cells. The EP was better when the average number of adhered cells was between 10 and 100 per microscopy field.
\end{abstract}

Key words: Bacterial adherence, Listeria innocua and Staphylococcus aureus, stainless steel, polycarbonate and polypropylene

\section{INTRODUCTION}

Bacterial adherence on inert food contact surfaces could lead to food contamination by undesirable microorganisms, resulting in food spoilage or transmission of disease (Bower et al, 1996; Hood, 1996; Jeong and Frank, 1994; Kumar and Anand, 1997; Stickler, 1999; Zottola and Sasahara, 1994). Bacterial adherence may trigger the process of microbial growth and biofilm formation and is a complex process that can be initiated with one bacterial cell and be affected by several factors such as microorganism species, growth conditions and polysaccharide production. The species that have cell appendages (fimbriae, pili and flagella) can bring the cells closer to the substrate and help the bacteria adhere to the surface (Austin et al., 1997; Dalton and March, 1998; O'toole, 1998). The hydrophobicity and charge surface of microorganisms affect their capacity to adhere to the surface (Hood 1996; Hood and Zottola, 1995). Growth conditions such as culture medium, $\mathrm{pH}$, salt concentration, organic compounds, time and temperature contact, agitation and substrate hydrophobicity and electric charge and its microtopography play an important role in bacterial adherence (Jeong and Frank, 1994; Smoot and Pierson, 1998; Zottola and Sasahara, 1994). Other important factor is the ability of the microorganisms to produce extracellular adhesive material that helps the cells to anchor to surface (Sticler, 1999; Zottola and Sasahara, 1994; Zottola, 1997)

A considerable number of surfaces used as food contact surfaces can promote microbial adherence process such as stainless steel, glass, cast iron, rubber, polypropylene, low-density polyethylene and polycarbonate (Andrade et al., Assanta et al.,

\footnotetext{
* Author for correspondence
} 
1998; Blackman and Frank, 1996; Flint et al.; 1997; Kumar and Anand, 1997; Zottola and Sasahara, 1994). Several techniques such as impedance measurement (Andrade et al., 1998a; Rule, 1997; Siley and Forshiyte, 1996), ATP bioluminescence (Stewart et al., 1997) and microscopy can be used to evaluate the bacterial adherence and biofilm formation. Microscopy techniques allow better visualization of the adherence process, growth and biofilm formation in food processing systems. Different microscopic techniques such as optical, epifluorescence, phase contrast, scanning electron, transmission electron and force atomic microscopy can be applied to evaluate cell adherence to the surfaces (Zottola, 1997). Epifluorescence microscopy (EP) is a good choice to determine the number of adhered cells on transparent or nontransparent surfaces since the cells become fluorescent after absorption of acridine orange permitting their microscopic observation. In this study, the efficiency of Staphylococcus aureus and Listeria innocua adherence on stainless steel, polypropylene and polycarbonate was evaluated by plate count $(\mathrm{CP})$ and epifluorescence microscopy methods.

\section{MATERIALS AND METHODS}

\section{Bacterial suspensions and culture media}

The studies on adherence were conducted using suspensions of Listeria innocua L6a and Staphylococcus aureus ATCC 6538. One hundred $\mu \mathrm{L}$ of these cultures were maintained at $-18^{\circ} \mathrm{C}$ on semi-solid media. For L. innocua growth, Tryptic Soy Broth (TSB-DIFCO) was used, with $0.6 \%$ of yeast extract and for $S$. aureus growth, Brain Heart Infusion (BHI-DIFCO) was used. A working culture was prepared by inoculating $100 \mu \mathrm{L}$ of frozen culture into $10 \mathrm{~mL}$ of TSB or BHI broth and by incubating at $30^{\circ} \mathrm{C}$ for $24 \mathrm{~h}$. The culture was sub-cultured twice before use.

\section{Attachment of cells}

The attachment of L. innocua and $S$. aureus on stainless steel, AISI 304, finish \# 4, on low-density polypropylene and on polycarbonate chips with dimensions of 10x10x1mm, 10x10x4 mm and 10x10x1 mm, respectively, was evaluated. The stainless steel and polypropylene chips were first immersed in acetone for $30 \mathrm{~min}$ followed by immersion in $1 \% \mathrm{NaOH}$ solution for $1 \mathrm{~h}$. After that they were rinsed with distilled water and sterilized at $121^{\circ} \mathrm{C}$ for $15 \mathrm{~min}$. The polycarbonate chips were immersed in ethyl alcohol for $1 \mathrm{~h}$, rinsed with distilled water, followed by UV exposure of $100 \mu \mathrm{W} / \mathrm{cm}^{2}$ for $1 \mathrm{~h}$. The sterile clean chips were added to flasks containing $100 \mathrm{ml}$ of TSB or BHI, which was previously inoculated with suspensions of L. innocua and $S$. aureus. The initial number of cells ranged from $10^{3}$ to $10^{4} \mathrm{CFU} / \mathrm{ml}$. The flasks were incubated, statically in a water bath at $30^{\circ} \mathrm{C}$. The number of adhered cells on the different surfaces was evaluated after $0,2,4,6,8,10$ and $12 \mathrm{~h}$ of contact time. The results were expressed in $\mathrm{CFU} / \mathrm{cm}^{2}$ of surface.

\section{Enumeration of adhered cells}

At each period of time, four chips were removed and rinsed for $1 \mathrm{~min}$ in two tubes - two chips/tube - containing $10 \mathrm{ml}$ of sterilized phosphate buffer $\left(\mathrm{KH}_{2} \mathrm{PO}_{4}, 0.31 \mathrm{M}, \mathrm{pH}\right.$ 7.2) to remove the nonadhered cells. Each chip was placed into a tube containing $2 \mathrm{ml}$ of phosphate buffer solution. Then, two tubes each containing a chip, were swirled with a vortex mixer for $2 \mathrm{~min}$. The cells released from the chip surface during the vortex mixing were diluted and spread on TSB or BHI agar plates, according to the type of microorganism, and incubated at $30^{\circ} \mathrm{C}$ for $48 \mathrm{~h}$. The other two chips were submitted to EP technique. Adhered cells found on chip surfaces after $1 \mathrm{~min}$ rinse were considered to be irreversibly attached to the surfaces. These attached cells were fixed to the chip surface with Kirkpatrick's solution (isopropyl alcohol: chloroform:formaldehyd-6:3:1), stained with $0.04 \%$ of acridine orange solution, and the chips were analyzed by epifluorescence microscope (FLUOVAR (Car/Zien - IENA). Each individual cell or group of cells was counted as DMC (Direct Microscopy Count). In this experiment, it was established that $1 \mathrm{DMC}$ was equal at $1 \mathrm{CFU}$. The average of cells per field was obtained from 5 or 10 observation fields. The $\mathrm{CFU} / \mathrm{cm}^{2}$ was determined by multiplying of the average number of cells per field the microscopy factor (4.500). The experiment was conducted in triplicates.

\section{Photomicrography}

The photomicrography of the microorganisms adhered to different surfaces was obtained by using Olympus BX 60 microscopy, coupled with an epifluorescence objective and an Olympus photo camera. 


\section{Statistical analyses}

Data were analyzed as a split-split plot design with the split - split plots consisting of two treatments: 1 - microorganism and surface types and 2 - time. The results were analyzed by regression and variance analysis using the Statistical Analysis System (SAS) (1988).

\section{RESULTS}

\section{Bacterial adherence to surfaces}

Fig. 1 shows the ability of L. inocua and S. aureus to adhere on stainless steel, polypropylene and polycarbonate surfaces at different contact times. Table 1 shows the analysis of variance of the $\log _{10}$ of the number of $L$. innocua and $S$. aureus adhered to surfaces, as determined by EP and CP methods. Significant differences $(p<0.05)$ were observed for the EP method in the interactions between microorganisms, surfaces and contact times.

\section{Epifluorescence Microscopy versus count plate after vortex mixing}

The results showed different numbers of adhered cells at 0 (zero) min contact time (Fig. 2) on the surface types when EP or $\mathrm{CP}$ techniques were used. For L. innocua, the $\log _{10}$ of the initial numbers determined by EP were $3.39 ; 3.42$; and 3.63 on stainless steel, polypropylene and polycarbonate, respectively. For the $\mathrm{CP}$ method, these values were $1.23,1.76$ and 1.47. For $S$. aureus, the $\log _{10}$ of the initial numbers determined by the EP technique were $3.75,3.46$ and 3.16 on the surfaces mentioned above. The values found by the CP method were $1.62,1.0$ and 0.54 .

After $10 \mathrm{~h}$, the $\log _{10}$ of the number of cells of $L$. innocua per $\mathrm{cm}^{2}$, as determined by EP, were 5.13, 5.10 and 4.68 , for stainless steel, polypropylene and polycarbonate, respectively. These values, as determined by $\mathrm{CP}$, were 4.0, 4.34 and 3.97. If the same incubation time and surfaces had been considered, the $\log _{10}$ of the number of cells of $S$. aureus adhered were 5.35, 4.95 and 4.90 by EP and $4.5,4.6$ and 4.5 , by CP. The results showed that the number of $L$ innocua adhered to stainless steel and $S$. aureus to polycarbonate was higher when counted by EP. However, the number of $S$. aureus adhered to polycarbonate and polypropylene was higher when determined by $\mathrm{CP}$.

\section{DISCUSSION}

In this experiment, the highest number of L. innocua or S. aureus adhered cells was between $10^{5}$ and $10^{6} \mathrm{CFU}$ per $\mathrm{cm}^{2}$, regardless of the surface studied. To be considered a biofilm, the number of adhered cells should range between $10^{6}$ and $10^{7} \mathrm{CFU}$ per $\mathrm{cm}^{2}$, which means $10-100$ folds above the values found. The results showed that the $\mathrm{CP}$ method has a better sensitivity to detect a low number of adhered cells than the EP method. This difference could be explained since by EP it was more difficult to count cells when the number on surfaces was still low in the early log-phase growth and initial adherence process. The number of adhered cells counted by $\mathrm{CP}$ was found to be lower than the number determined by EP. A likely explanation for these results was the fact that $\mathrm{CP}$ was not able to remove all irreversibly adherent cells from the surfaces after vortex mixing the chips immersed in the phosphate buffer solution contained in the tubes. The vortex method failed to totally remove all attached cells. It was also possible that in this experiment, the growth conditions for a considerable number of cells were not enough.

The results showed that the EP was better than CP, particularly when the average number of adhered cells per microscopic observation field range between 10 and 100 . In these values, the count range by $\mathrm{EP}$ was between $4.5 \times 10^{4}$ and $4.5 \times 10^{5}$ CFU per $\mathrm{cm}^{2}$.

The number of adhering cells on the surface of the chips increased as a function of contact time and depended on the method used for enumeration. For example, the $\log _{10}$ of the $L$. innocua numbers attached after $10 \mathrm{~h}$, determined by EP, were 5.13 , 5.1 and 4.68 in stainless steel, polypropylene and polycarbonate, respectively. For CP, these numbers were 4.0, 4.34, and 3.97.

These values indicated an adherence process of the microorganisms on the surfaces studied. The use of microscopy to count adhered cells on surface chips is a viable technique, since, on a microscopic scale, surfaces can be found to have cracks and crevices, quite unlike macroscopic appearance. These surface imperfections protect the microorganisms against removal by swab or rinse, for example. Thus, they will not be enumerated by plate count methods. 


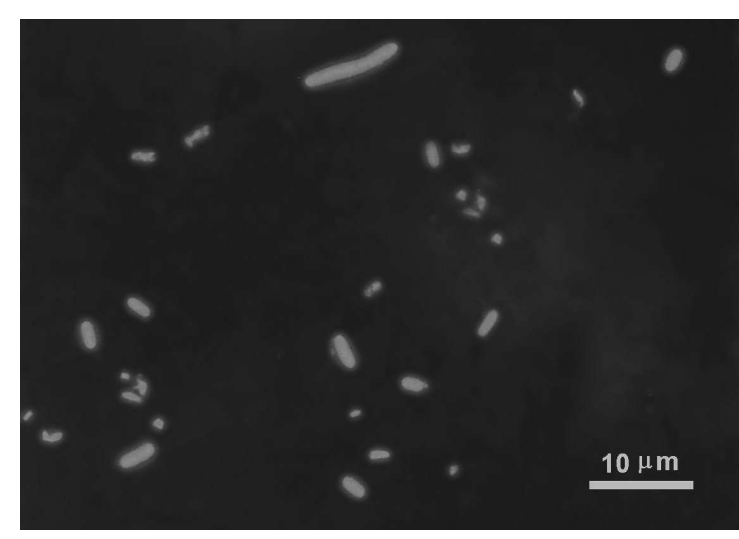

A

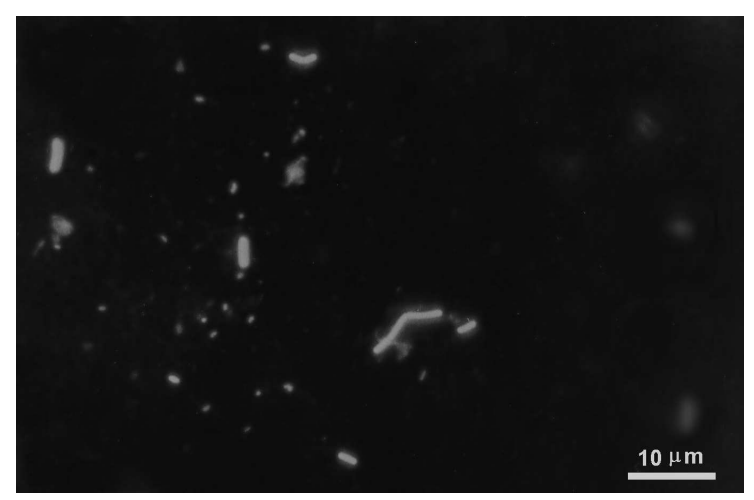

C

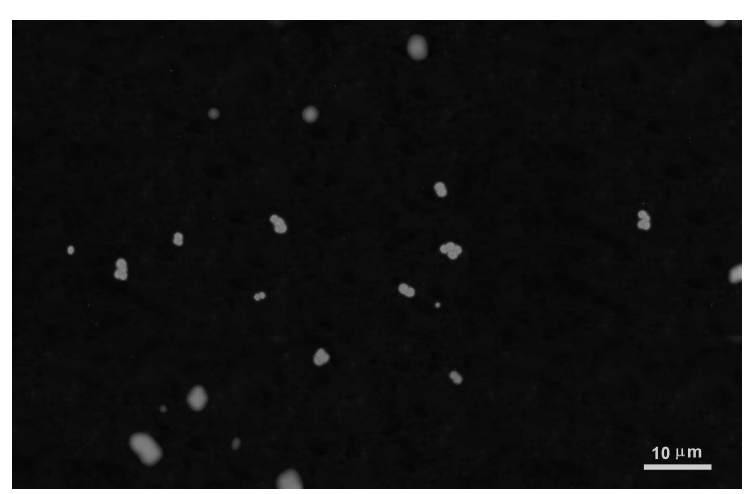

E

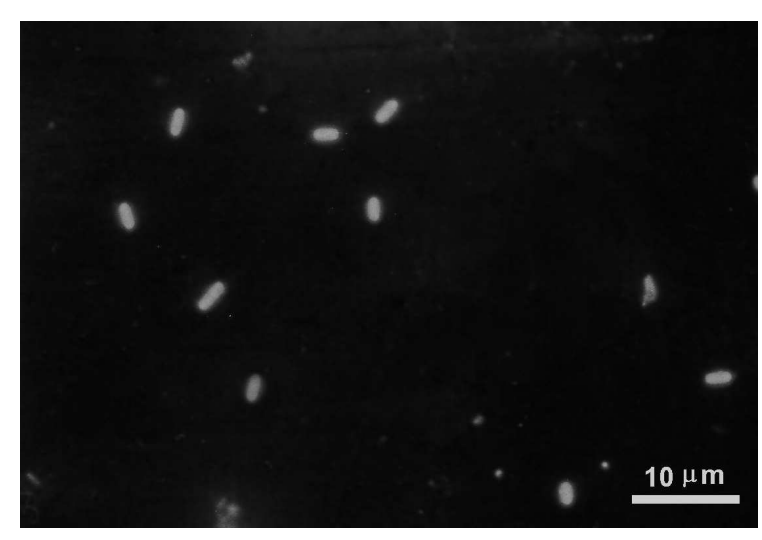

B

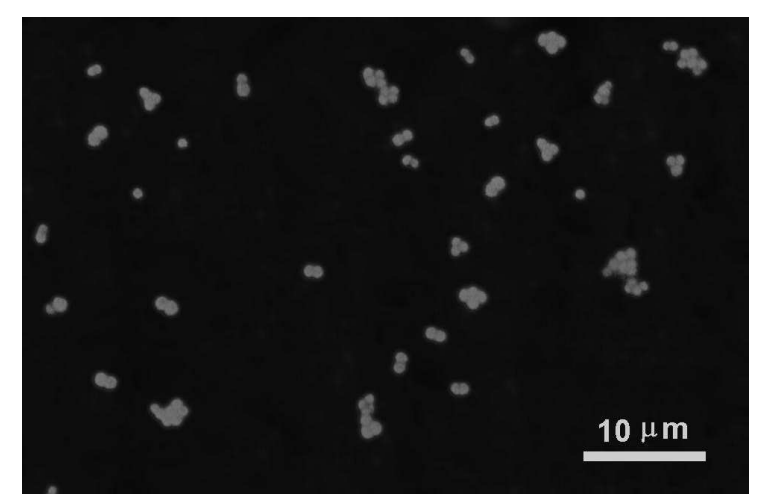

D

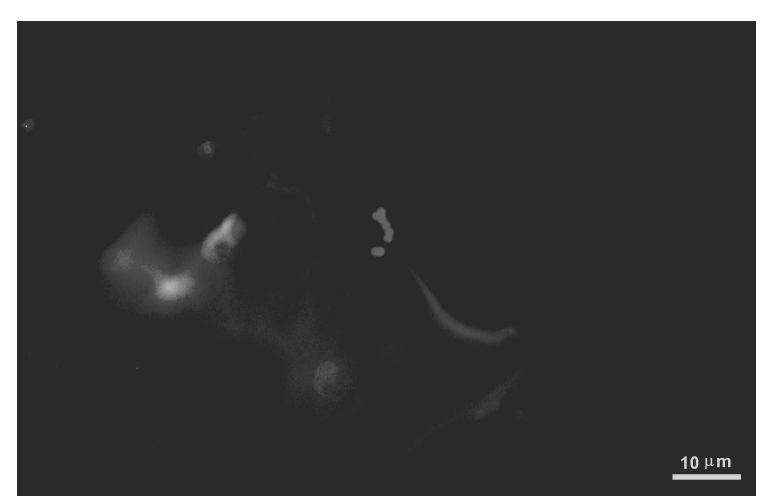

F

Figura 1 - Photomicrography of bacterial adherence on different surfaces by epifluorescence microscopy, after growth in TSB at $30^{\circ} \mathrm{C}$. A, C: Listeria innocua L6a adhered on stainless steel, AISI 304, \# 4, after 12h of incubation. B: Listeria innocua L6a adhered on propylene, AISI 304, after 10h of incubation. D and E: Staphylococcus aureus adhered on stainless steel, AISI 304, \#4, and polycarbonate, after $12 \mathrm{~h}$ of incubation. F: Staphylococcus aureus adhered on polypropylene after $10 \mathrm{~h}$ of incubation. 
Table 1 - Analysis of variance of the $\log _{10}$ of the number $\left(\mathrm{CFU} / \mathrm{cm}^{2}\right.$ of Staphylococcus aureus ATCC 6538 and Listeria innocua L6a, adhered to different surfaces

\begin{tabular}{l|c|c|c|c|c}
\hline \multicolumn{3}{c}{ Epifuorescence Method } & \multicolumn{2}{c}{ Plate Count Method } \\
\hline \multicolumn{1}{c}{ VF } & LG & MS & P (F) & MS & P (F) \\
\hline Bacteria (B) & 1 & 0.0028 & 0.9008 & 0.1731 & 0.4773 \\
Surface (S) & 2 & 0.8545 & $0.0262^{*}$ & 0.8069 & 0.1229 \\
Interaction BxS & 2 & 0.5614 & 0.0725 & 1.0801 & 0.0694 \\
Error (a) & 12 & 0.1705 & & 0.3216 & $0.0001^{*}$ \\
Time (T) & 6 & 8.4780 & $0.0001^{*}$ & 31.8189 & 0.2439 \\
SxT & 12 & 0.0852 & $0.0055^{*}$ & 0.2079 & $0.0010^{*}$ \\
BxT & 6 & 0.0568 & 0.1189 & 0.6882 & 0.0674 \\
BxSxT & 12 & 0.0756 & $0.0133^{*}$ & 0.2875 & 0.1613 \\
Error (b) & 72 & 0.0322 & & &
\end{tabular}

*Significant at $5 \%$ probability $(\mathrm{p}<0.05)$.

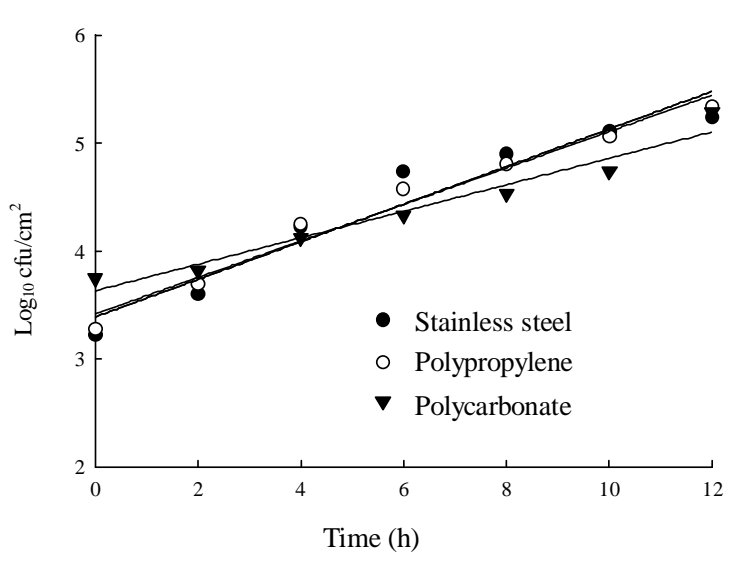

A

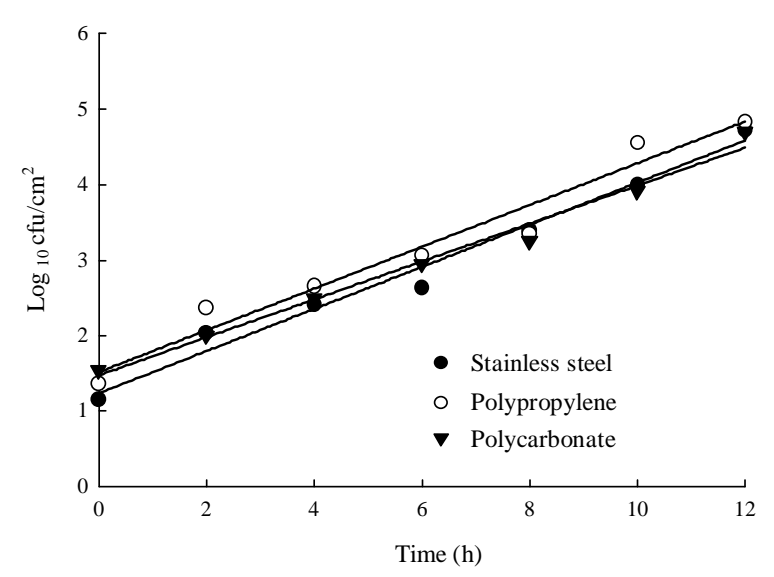

C

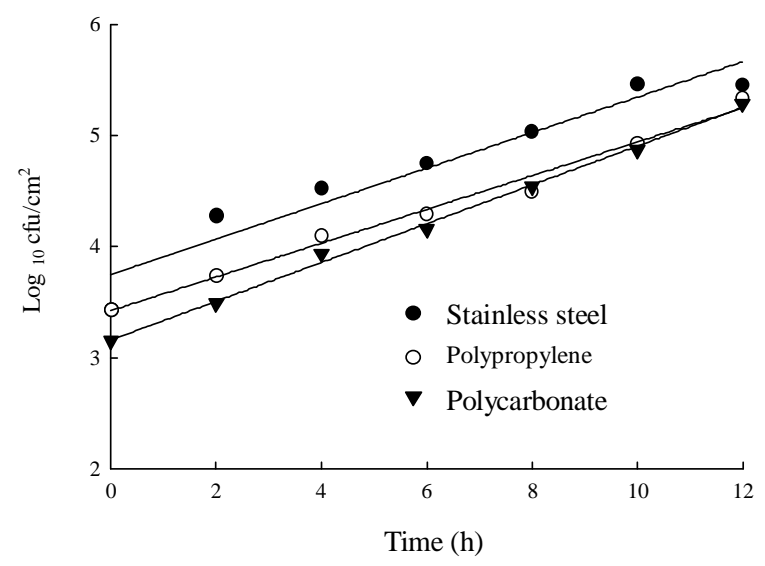

B

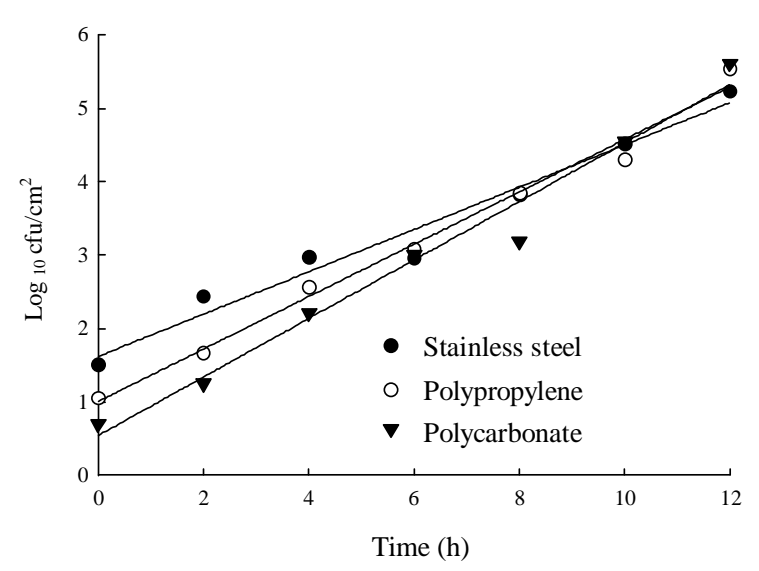

D

Figure 2 - $\log _{10}$ of the number of bacterial cells adhered on different surfaces as a function of contact time. (A) and (C): adherence of Listeria inoccua L6a, as determined by EPM and CPM, respectively. D and B: adherence of Staphylococcus aureus ATCC 6538, as determined by EPM and CPM, respectively. 
Microscopes coupled with image analysis systems can help the count process of adhered cells on surfaces by EP. The use of image analysis systems renders the EP a viable alternative to quantify adherence. Currently, the determination of the percentage area covered by bacterial growth on surfaces by software, combined with epifluorescence microscopy, has improved the evolution of the adherence process and biofilm formation.

\section{ACKNOWLEDGMENTS}

The authors would like to thank $\mathrm{CNPq}$ and FAPEMIG for their financial support.

\section{RESUMO}

A adesão de Listeria innocua L6a e de Staphylococcus aureus ATCC 6538 foi avaliada em cupons de prova de aço inoxidável AISI 304, de policarbonato, ambos com dimensões de 10x10x1mm, e de polipropileno com dimensões de 10x10x4mm. Os cupons limpos e esterilizados foram imersos em $100 \mathrm{~mL}$ de caldo TSB ou de BHI, contendo cerca de $1,0 \times 10^{3} \mathrm{UFC} / \mathrm{ml}$ de $L$. innocua ou de $S$. aureus, respectivamente, e incubados a $30^{\circ} \mathrm{C}$. Após $0,2,4,6,8,10$ e 12 horas, os cupons foram retirados e imersos em tampão fosfato $(0,31 \mathrm{M}$ e $\mathrm{pH}=7,2)$, durante 1 minuto, para remoção de células planctônicas; em seguida, submetidos à determinação do número de células aderidas pelas técnicas da microscopia de epifluorescência (MEP) e da contagem-padrão em placas após vórtex (CPP). Para MEP, os cupons foram imersos em solução de Kirkpatrick durante 3 minutos para fixar as células às superfícies. Posteriormente, as células foram coradas com alaranjado de acridina durante 5 minutos, e enumeradas pela MEP, em objetiva de imersão com área de $0,0226 \mathrm{~mm}^{2}$. Para CPP, os cupons foram imersos em $2 \mathrm{~mL}$ de tampão fosfato, submetidos ao vórtex, durante 1 minuto, para remoção das células sésseis, e, em seguida, foram efetuadas as contagens, usando-se ágar BHI ou TSB e incubação a $30^{\circ} \mathrm{C}$ por 48horas. Os resultados, tanto para MEP quanto para CPP, foram expressos em UFC/ $/ \mathrm{cm}^{2}$. Para a técnica de MEP, constatou-se diferença significativa $(p<0,05)$ quando se avaliaram as interações entre os microrganismos, as superfícies e os tempos de contato. Verificou-se que o número de células aderidas aumentou com o tempo de contato, para todas as superfícies, independente do microorganismo. A CPP mostrou-se mais sensível para detectar números baixos de células aderidas às superfícies. No entanto, de forma geral, as contagens bacterianas obtidas pela CPP eram menores do que aquelas obtidas pela MEP. Podese afirmar que a MEP foi a técnica mais adequada para quantificar a adesão bacteriana, principalmente, quando o número de células aderidas às superfícies, observadas nos campos microscópicos, encontrava-se entre 10 e 100.

\section{REFERENCES}

Andrade, N. J.; Bridgeman, T. A. and Zottola, E. A. (1988), Bacteriocidal activity of sanitizers against Enterococcus faecium attached to stainless steel as determined by plate count and impedance methods. Journal Food Protection, 61, 833-838.

Andrade, N. J.; Ajao, D. B. and Zottola, E. A. (1988), Growth and adherence on stainless steel by Enterococcus faecium cells. Journal of Food Protection, 61 : (11), 1454-1458.

Assanta, M. A.; Roy, D. and Montpetit, D. (1988), Adhesion of Aeromonas hydrophila to water distribution systems pipes after different contact times. Journal of Food Protection, 61, (10), 614-618.

Austin, J. W.; Sanders, G.; Kay, W. W. and Collinson, S. K. (1997), Thin aggregative fimbriae enhance Salmonella enteritidis biofilm formation. FEMS Microbial Letters, 212 : (162), 295-301.

Blackman, I. and Frank, I. F. (1996), Growth of Listeria monocytogenes as a biofilm on various food processing surfaces. Journal Food Protection, 59, 827-831.

Bower, C. K.; Mc Guire, J. and Daeschel, M. A. (1996), The adhesion and detachment of bacteria and spores on food-contact surfaces. Trends in Food Science and Technology, 7, 152-157.

Dalton, H. M. and March, P. E. (1998), Molecular genetics of bacterial attachment and biofouling. Current Opinion in Biotechnolgy, 9, 252-255.

Flint, S. H.; Bremer, P. J. and Brooks, J. D. (1997), Biofilms in dairy manufacturing plant - Description, current concerns and methods fo control. Biofouling, 11 : (1), 81-87.

Hood, S. K. (1996), Adherence of foodborne microorganisms to stainless steel. Ph.D thesis. University of Minnesota, Saint Paul. 129 pp.

Hood, S. and Zottola, E. A. (1995), Biofilms in food processing. Food Control, 6, 8-18. 
Jeong D. K. and Frank, J. F. (1994), Growth of Listeria monocytogenes at $10^{\circ} \mathrm{C}$ in biofilms with microorganisms isolated from meat and dairy processing environments. Journal of Food Protection, 57 : (7), 576-586.

Kumar, C. G. and Anand, S. K. (1997), Significance of microbial biofilms in food industry: a review. International Journal of Food Microbiology, 34, 179-186.

O'toole, G. A. and Kolter, R. (1998), Flagellar and twitching motility are necessary for Pseudomonas aeruginosa biofilm development. Molecular Microbiology, 28, 449-461.

Rule E, P. (1997), Measurement of microbial activity by impedance. In: Tortorello M. L. and Grendel, S. M. (Eds.). Food microbiologist analysis: new technologies. Baltimore: IFT basic symposium series. p.305-314.

Siley, P. and Forshiyte, S. A. (1996), A review: impedance microbiology - a rapid change for microbiologist. Journal Applied Bacteriology, 80, 233-243.

Smoot, L. M. and Pierson, M. D. (1998), Effect of environmental stress on the ability of Listeria monocytogenes Scott A to food contact surfaces. Journal of Food Protection, 61 : (10), 1293-1298.

Statistical Analysis Systems SAS/STATTM (1988), User's Guide, Release 6.03 edition. Cary, NC : SAS Institute Inc. pp. 1028.

Stickler, D. (1999), Biofilms. Current Opinion in Biotechnology, 10, 270-275.

Stewart, G. S. A. B.; Aldsworth, T. G.; Sharman, R. L. and Gibson, P. T. (1997), Bioluminescence: lux as an enabling tool for the microbiological analysis. In: Tortorello, M. L. and Grendel, S. M. (Eds.). Food microbiologist analysis: new technologies. Baltimore : IFT basic symposium series. pp.265-288.
Zottola, E. A. and Sasahara, K. C. (1994), Microbial biofilms in the food processing. Should they be a concern? International Journal Food Microbiology, 23, 125-148.

Zottola, E. A. (1997), Special techniques for studying microbial biofilms in systems. In: Tortorello, M. L., Grendel, S.M. (Eds.). Food microbiologist analysis: new technologies. Baltimore : IFT basic symposium series. pp. 315-343.

Received: May 08, 2002; Revised: July 24, 2002; Accepted: December 06, 2002. 